\title{
Bimbingan Akhlak pada Anak melalui Sistem Halaqah Quran
}

\author{
Sinta Hajrina ${ }^{1 *}$, Dudy Imanudin Effendi ${ }^{2} \&$ Abdul Mujib ${ }^{3}$ \\ 123Jurusan Bimbingan dan Konseling Islam, UIN Sunan Gunung Djati, Bandung \\ *Email : sintahajrina@gmail.com
}

\begin{abstract}
ABSTRAK
Penelitian ini bertujuan Untuk mengetahui Bimbingan Akhlak pada Anak melalui Sistem Halaqah Quran di SD Al-Quran, untuk mengetahui Faktor Penunjang dan Penghambat Bimbingan Akhlak pada Anak melalui Sistem Halaqah Quran di SD Al-Quran, serta untuk mengetahui hasil yang dicapai dari Bimbingan Akhlak pada Anak melalui Sistem Halaqah Quran di SD Al-Quran. Penelitian ini menggunakan metode deskriptif kualitatif, yaitu menerapkan fenomena sosial atau suatu peristiwa apa adanya. Dari hasil penelitian diperoleh bahwa bimbingan akhlak pada anak melalui sistem Halaqah Quran diketahui berlangsung dengan efektif dan cukup berhasil. Dampaknya dapat dirasakan oleh Guru Al-Quran selaku pembimbing dan orang tua siswa yang melaporkan perubahan akhlak siswa yang diaplikasikan di rumah. Secara pemahaman, siswa sudah mampu memahami bagaimana akhlak yang baik yang harus dilakukan. Diantaranya Akhlak kepada Allah Swt, Akhlak kepada sesama dan Akhlak kepada lingkungan.
\end{abstract}

Kata Kunci : Bimbingan; Akhlak; Anak; Halaqah; Quran.

\begin{abstract}
This research aims to find out the Moral Guidance in Children through the Halaqah Quran System at SD Al-Quran, to find out the Supporting Factors and Inbibitors of Moral Guidance on Children through the Halaqah Quran System in the Al-Quran Koran. and to find out the results achieved from Moral Guidance on Children through the Halaqah Quran System in the Al-Quran Elementary School. This study uses descriptive qualitative method, which implements social phenomena or event as they are. From the results of the study, it was found that moral guidance in children through the Halaqah Quran system was known to be effective and quite successful. The impact can be felt by Al-Quran Teachers as mentors and parents of students who report students'moral changes applied at home. In understanding, students have been able tounderstand how good morals must be done. Among there are morals to Allah, morality to others, and morals to the environment.
\end{abstract}

Keywords : Guidance; Morals; Child; Halaqab; Quran.

Diterima: Maret 2020. Disetujui: Mei 2020. Dipublikasikan: Juni 2020. 


\section{PENDAHULUAN}

Anak adalah anugerah dari Allah Swt yang diamanahkan kepada suatu keluarga untuk dipelihara dan dijaga keselamatannya baik keselamatan dunia maupun keselamatan Akhirat. Merawat anak bukanlah perkara yang mudah karena didalamnya diperlukan kasih sayang dan tanggung jawab untuk membimbing, mendidik dan membesarkan anak sampai usia baligh dan dewasa. Oleh karena itu orang tua berkewajiban untuk memperhatikan segala aspek tumbuh kembang anak untuk dibimbing dengan baik, guna memenuhi bekal hidup agar anak siap secara fisik dan mental menghadapi dan mengatasi permasalahan hidup yang akan anak hadapi dan kelak dapat menjadi orang yang bermanfaat bagi diri, keluarga dan lingkungan.

Namun bimbingan yang diberikan oleh orang tua tidaklah cukup untuk memenuhi bekal kehidupannya yang akan datang. Fitrah manusia yang hidup sebagai mahluk sosial, sehingga mambutuhkan orang lain. Anakpun perlu belajar dari lingkungan luar seperti di lebaga formal maupun nonformal guna menyeimbangkan pengetahuan.

Setiap anak memiliki karakter yang unik sehingga menghasilkan bermacam-macam perilaku. Anak terus belajar menyesuaikan diri dari lingkungan dan ajaran yang telah diterima. Perilaku anak perlu diolah dengan penanaman akhlakul karimah, karena akhlak memiliki kedudukan yang tinggi dalam Al-Quran. Salah satu isi pokok dalam Al-Quran adalah pengajaran tentang akhlak. Sebagaimana Rasulullah Saw diutus dimuka bumi untuk menyempurnakan Akhlak yang mulia. Seperti yang dijelaskan dalam hadist:

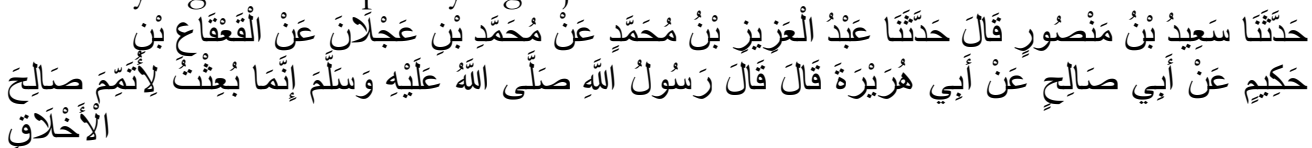

"Telah menceritakan kepada kami Sa'id bin Mansur berkata, telah menceritakan kepada kami Abdul Aziz bin Muhammad dari Muhammad bin 'Ajlan dari Al-Qa'qai bin Hukaim dari Shalih dari Abu Hurairah RA berkata: Rasulullah Saw Bersabda: "Sesungguhnya aku diutus untuk menyempurnakan akhlak yang baik" (HR. Ahmad dan ditashih oleh Baihaqi menurut Syarat Muslim).

Jika hadis di atas dicermati dengan baik, dapat dikatakan bahwa tujuan mendasar diutusnya Rasulullah Saw berkaitan dengan akhlak. Rasulullah Saw mempunyai peran yang besar untuk membimbing umatnya menuju jalan yang lurus. karena Akhlak pada dasarnya dapat dibentuk. Akhlak dapat berubah sesuai kadar keimanan seseorang dan kuatnya lingkungan yang mempengaruhi baik pengaruh dari luar maupun dari dalam.

Kedudukan akhlak dalam islam amat jelas. Terdapat banyak ayat al-Quran dan hadits Rasulullah Saw yang menunjukkan bahwa peranan akhlak dalam islam 
tidak boleh dipisahkan dari kandungan agama itu sendiri. Dengan kata lain agama islam sangat berkaitan erat dengan menekankan soal akhlak. Oleh karena itu istilah akhlak juga dimaknai dengan agama karena ia merupakan bagian dari agama islam itu sendiri. Sering kali soal kesempurnaan iman atau akidah seorang muslim dikaitkan dengan amalan nilai akhlak, karena akhlak dalam Islam ialah nilai keagamaan dan nilai kudus yang perlu dipelihara (Suhid, 2009:19)

Sementara melihat dewasa ini, banyak fenomena kemerosotan moral dan perilaku dimana anak menjadi pelaku utama. Kecanggihan teknologi dan informasi menjadi sarana yang mudah untuk dipelajari anak. Tanpa adanya filtrasi, anak dapat menampung segala macam informasi baik ataupun buruk. padahal anak belum sepenuhnya dapat menilai hal yang baik dan benar sehingga anak dapat mudah terpengaruh kepada hal yang negatif.

Ciri anak yaitu memiliki dorongan tinggi untuk keluar dari lingkungan rumah dan memasuki dunia kelompok teman sebaya. Perilaku teman sebaya memiliki pengaruh yang besar. Seperti halnya siswa SD Al-Quran, yang memiliki masalah ketika siswa pindahan masuk ke lingkungan sekolah dengan membawa kultur baru. Kultur yang dibawa bersifat kurang baik dan dengan mudah diterima oleh siswa SD Al-Quran. Contohnya berkata kasar dan kotor, berkelahi dengan teman, mendengarkan musik, padahal siswa SD Al-Quran tidak diperdengarkan musik demi terjaganya kualitas hafalan Al-Quran. (wawancara dengan ibu Ditje, tanggal 16 Juli 2018).

Oleh karena itu bimbingan Akhlak dirasakan sangat penting untuk mengarahkan anak kepada kebaikan. Apalagi untuk usia anak yang terbilang sangat efektif untuk membentuk perilaku baik sedari dini. Bimbingan Akhlak pada anak diperlukan agar anak dapat mengetahui bagaimana berkahlak baik kepada Allah, kepada diri sendiri, kepada orang tua, kepada guru dan kepada teman sebaya.

Berbicara mengenai akhlak sama dengan berbicara tentang tujuan pendidikan. karena banyak lembaga pendidikan yang memiliki tujuan untuk membentuk siswanya berakhlakul karimah. Begitu pula dengan tujuan SD AlQuran untuk membentuk siswanya menjadi siswa yang cerdas, berakhlakul karimah dan hafidz Quran. Dari hasil wawancara bersama ibu Ditje selaku koordinator Al-Quran pada tanggal 16 Juli 2018, SD Al-Quran menerapkan 30\% kegiatan pelajaran umum dan $70 \%$ kegiatan kealquranan dengan menerapkan sistem Halaqah sebagai metode pembelajaran.

Kegiatan Halaqah sudah berlangsung saat Rasulullah mendakwahkan islam secara sembunyi-sembunyi hingga berkembang sampai saat ini. Kegiatan Halaqah memiliki manfaat yang besar diantaranya memupuk ukhuwah islamiyah, karena sistem Halaqah lebih bersifat kekeluargaan. Terkait dengan kebutuhan anak yang pada usianya banyak berinteraksi dengan teman sebaya, tentunya sistem Halaqah dapat menjadi sebuah wasilah untuk mengintegrasikan pendidikan 
dengan akhlak anak.

Adapun literatur yang berkaitan dengan penelitian merujuk pada skripsi terdahulu yaitu skripsi Ali Zubair dengan judul "Bimbingan Akhlak Karimah pada Siswa Sekolah Dasar Islam Terpadu Salsabila Klaseman, Sinduharjo, Ngalik, Sleman, Yogyakarta" isi pokoknya membahas mengenai bimbingan Akhlak pada anak usia sekolah yaitu siswa kelas dua sebagai sampel penelitian dengan menggunakan metode bintang prestasi sebagai penerapannya. Sementara penulis meneliti sistem halaqah Quran yang diterapkan kepada anak usia sekolah yaitu anak kelas 2 atau setara dengan anak usia tujuh sampai delapan tahun. Sistem halaqah Quran ini menjadi tumpuan untuk penerapan bimbingan Akhlak.

Penelitian Hikmat (2016) mengenai bimbingan akhlak dalam pencegahan perilaku narsisme remaja. Penelitian dilakukan di kawasan Bandung Timur meliputi 137 remaja SLTA. Hasil penelitian menunjukkan bahwa tingkat narsisme remaja sekolah di Bandung Timur, berada pada kategori sedang. Perilaku narsisme remaja berada pada posisi yang aman, sebab perilaku tersebut cenderung akan mengalami peningkatan. Oleh karena itu, perlu adanya upaya pecegahan secara komprehensif sejak dini, oleh orang tua masyarakat dan pihak sekolah. Penelitian Gustini (2016) mengenai bimbingan akhlak berbasis pemikiran Imam Al-Ghazali. Penelitian dilakukan terhadap siswa MAN 1 Bandung. Penelitian ini menggunakan pendekatan campuran kualitatif dan kuantitatif. Hasil penelitian menunjukkan akhlak mulia siswa menurut aspek kekuatan ilmu berkategori sedang, aspek kekuatan mengendalikan marah berkategori tinggi, aspek kekuatan mengendalikan syahwat berkategori sedang, aspek kekuatan adil berkategori tinggi.

Penelitian Chodijah (2016) mengenai bimbingan dan konseling komprehensif terhadap mahasiswa. Bimbingan dan konseling komprehensif dalam penelitian ini meliputi akademik, sosial-pribadi dan karir. Penelitian dilakukan dengan metode research and development, dimana chodijah menyatakan bahwa bimbingan dan konseling mahasiswa di perguruan tinggi berjalan kurang efektif. Penelitian Lusiyana, Rohman dan Rohim (2018) mengenai peran bimbingan konselin bagi siswa MA. Penelitian dilakukan merujuk pada perspektif konseling berbasis tiga pilar konselor yakni guru, orang tua dan lingkungan masyarakat. Hasil penelitian menunjukkan bahwa keberhasilan peserta didik tidak hanya ditentukan oleh lembaga pendidikan saja, tetapi juga ada peran aktif dari guru, orang tua dan lingkungan masyarakat tempat peserta didik mengaktualisasikan segala pengetahuan dan pengalamannya.

Sementara itu, penelitian berkaitan dengan sistem halaqah pernah dilakukan oleh Nashir dan Halib (2016). Penelitian difokuskan pada pengaruh sistem pembinaan halaqah pada kecerdasan santri tahfidz Markaz Al-Birr. Hasil penelitian menunjukkan bahwa sistem pembinaan halaqah qur'an dalam bentuk sistem tahsin, privat dan mandiri terbukti mampu meningkatkan kecerdasan 
emosional santri. Selain itu, faktor pendukung seperti dorongan orang tua dan lingkungan berpengaruh secara signifikan dalam proses pembinaan. Penelitian Armansyah (2018) mengenai penerapan pembinaan halaqah dalam peningkatan kecerdasan emosional. Hasil penelitian menunjukkan bahwa pembinaan halaqah menjadi ruang meditor bagi setiap orang untuk memahami potensi dirinya mencakup kecerdasan mengenali emosi diri, mengelola emosi, memotivasi diri sendiri, mengenali emosi orang lain, bahkan membina hubungan.

Penulis menentukan tempat penelitian di SD Al-Quran yang beralamatkan di Komplek LPTQ Jl. A.H Nasution no 247 Mandalajati, Bandung. Penulis mengambil tempat penelitian tersebut karena terdapat masalah yang berkaitan eran dengan yang penulis teliti.

Dari latar belakang masalah tersebut dapat dirumuskan beberapa masalah dengan rumusan masalah: bagaimana bimbingan akhlak pada anak melalui sistem Halaqah Quran? Apa faktor penunjang dan penghambat bimbingan akhlak pada anak melalui sistem halaqah Quran? dan bagaimana hasil yang dicapai dari bimbingan akhlak pada anak melalui sistem halaqah Quran? Metode yang digunakan dalam penelitian ini adalah metode deskriftif kualitatif, dengan mengamati fenomena atau suatu peristiwa dan menganalisis hasil pengumpulan data melalui observasi dan wawancara dengan kepala sekolah, koordinator alQuran, selaku pihak pengelola dan guru Al-Quran. sampel dalam penelitian ini adalah siswa SD kelas 2 dengan diamati perubahan akhlak sebelum dan sesudah kegiatan bimbingan.

\section{LANDASAN TEORITIS}

Penelitian ini berpijak pada teori bimbingan akhlak pada anak dan Halaqah Quran. Bimbingan merupakan terjemahan dari "Guidance” yang berarti mengarahkan, memandu, mengelola dan menyetir. Bimbingan menurut Dewa Kentut Sukardi adalah proses pemberian bantuan kepada seorang atau sekelompok orang secara terus menerus atau sistematik oleh guru pembimbing agar individu atau kelompok individu menjadi pribadi yang mandiri (Satriah, 2016: 37).

Sementara bimbingan dalam kajian ilmu dakwah dikenal dengan istilah Irsyad, Irsyad Islam Menurut Isep Zaenal Arifin berarti proses peberian bantuan terhadap diri sendiri (Irsyad Nafsiah), individu (Irsyad Fardiyah) dan kelompok kecil (irsyad fiah qalilah) agar dapat keluar dari berbagai kesulitan untuk mewujudkan kehidupan pribadi, individu dan kelompok yang salam, hasanah thaybah dan memperoleh ridha Allah dunia akhirat (Arifin, 2008: 35)

Unsur bimbingan diantaranya karakteristik pembimbing, dalam wilayah bimbingan dan konseling Islam, seorang pembimbing dikenal dengan sebutan mursyid.

Mursyid secara fungsional dapat diartikan sebagai penolong dan 
mencocokan perilaku dengan tuntunan ajaran dari Allah, pemberi petunjuk ke jalan yang benar dan baik, pembimbing yang menjalankan ajaran yang datang dari Allah. Karakteristik mursyid diantaranya: 1) Sifat nafsiyah contohnya ikhlas, optimis, semangat, qanaah, sabar dll. 2) sifat jasadiyah contohnya rapi, bersih, sehat, dan berpenampilan baik. 3) Sifat ijtimaiyah contohnya berbudi pekerti baik, menepati janji, dan berani mengatakan kebenaran (Enjang \& Mujib: 2009)

Metode bimbingan dapat diklasifikasikan berdasarkan segi komunikasi. Pengelompokannya yaitu: Pertama, metode komunikasi langsung atau disingkat metode langsung (bertatap muka) dan kedua, metode komunikasi tidak langsung atau metode tidak langsung. Metode langsung salahsatunya yaitu metode kelompok.

Bimbingan kelompok (group guidance), ada kontak antara ahli bimbingan dengan sekelompok klien yang agak besar, mereka mendengarkan ceramah, ikut aktif berdiskusi, serta menggunakan kesempatan untuk tanya jawab. Pembimbing banyak menggunakan inisiatif dan memrgang peranan instruksional, misalnya bertindak sebagai instruktur atau sumber ahli bagi berbagai macam pengetahuan atau informasi. Tujuan utama dari bimbingan kelompok ini adalah penyebaran informasi mengenai penyesuaian diri dengan berbagai kehidupan klien (Amin, 2002: 71)

Kemudian berlanjut kepada konsep akhlak, sebagaimana urgensi akhlak bahwa "Islam adalah Akhlak, seluruh Syariat kepada umat mempunyai nilai-nilai akhlak dan membina akhlak manusia, baik yang berupa akidah dan keimanan, maupun yang berupa ibadah" (Syukur, 2002). Dari segi bahasa "akhlak adalah bentuk jama' dari "Khuluq" yang artinya tingkah laku, tabiat, watak, perangai, atau budi pekerti” (Subarsono, 1989: 129).

Dalam pengertian sehari-hari akhlak umumnya disamakan artinya dengan budi pekerti, kesusilaan, sopan santun dalam bahasa Indonesia, dan tidak berbeda pula dengan arti kata moral, ethic dalam bahasa inggris. Manusia akan menjadi sempurna jika mempunyai akhlak terpuji serta menjauhkan segala akhlak tercela (Mansur, 2009: 221).

Akhlak menurut Anis Matta adalah "nilai dan pemikiran yang telah menjadi sikap mental yang mengakar dalam jiwa, kemudian tampak dalam bentuk tindakan dan perilaku yang bersifat tetap, natural atau alamiah tanpa dibuat-buat, serta refleks" (Matta, 2006: 14).

Ruang lingkup Akhlak terbagi menajdi dua bagian. Pertama, Akhlak berdasarkan sifatnya diantaranya Akhlak Mahmudah (Akhlak terpuji) atau Akhlak Karimah (Akhlak mulia). Contoh dari akhlak terpuji adalah taubat, Amar ma'ruf nahi mungkar, syukur, tawakkal, qanaah, dan tawadhu. Sementara Kedua, Akhlak Mazmumah (Akhlak tercela) yang terbagi menjadi dua bagian: 1) Maksiat Lahir (Maksiat lisan, telinga, mata, dan tangan). 2) Maksiat Batin contohnya yaitu: 
Takkabur, Syirik, Nifaq, iri hati atau dengki, marah, dsb.

Selanjutnya membahas mengenai anak, Menurut Sugiri yang mengutip buku karya Maidi Gultom mengatakan bahwa:

Selama di tubuhnya masih berjalan proses pertumbuhan dan perkembangan, anak itu masih menjadi anak dan baru menjadi dewasa bila proses perkembangan dan pertumbuhan itu selesai, jadi batas umur anakanak adalah sama dengan permulaan menjadi dewasa, yaitu 18 (delapan belas) tahun untuk wanita dan dua puluh satu tahun untuk laki-laki (Sugiri: 2010)

Anak memiliki tumbuh kembang yang berbeda, dari berbagai teoripun pandangan terhadap anak memiiki paradigma yang berbeda. Namun anak juga diiringi dengan ciri khas atau karakteristik yang menonjol dalam dirinya. Tentu hal tersebut dapat menjadi tolok ukur untuk sebuah pencapain tugas perkembangan sang anak. Anak melewati beberapa masa, dianatarnya masa bayi, masa kanakkanak, masak anak-anak sekolah, masa remaja dan masa pubertas awal.

Kemudian berangkat kepada konsep Sistem Halaqah Quran. Halaqah secara bahasa artinya lingkaran. Kalimat halqah min al-nas (الناس من حلقة) artinya kumpulan orang yang duduk. (A.W. Munawwir, 1997:290)

Halaqah menurut istilah adalah sesuatu hubungannya dengan dunia pendidikan, khususnya pendidikan atau pengajaran Islam (tarbiyah Islamiyah). Istilah Halaqah (lingkaran) biasanya digunakan untuk menggambarkan sekelompok Muslim yang secara rutin mengkaji ajaran Islam. Organisasi yang menaungi Halaqah tersebut (Lubis, 2011: 16)

Pengertian lain dari halaqah adalah proses belajar mengajar yang dilaksanakan murid-murid dengan melingkari guru yang bersangkutan. Biasanya duduk dilantai serta berlangsung secara terus menerus untuk mendengarkan seorang guru membacakan dan menerangkan kitab karangannya atau memberi komentar atas karya orang lain (Munawaroh, 2009: 16).

Jadi, inti dari Halaqah adalah lingkaran. Implikasinya yaitu suatu sistem pembelajaran dengan duduk melingkari guru, dan memperhatikan dengan sekasama apa yang diajarkan oleh guru. Sistem Halaqah ini terdiri dari kelompokkelompok kecil. Sistem Halaqah atau weton (bahasa jawa) adalah sistem tertua di pesantren dan tentunya merupakan inti pengajaran di suatu pesantren. Semuanya tidak lepas dari konteks historis lahirnya lembaga pendidikan Islam klasik yang pada awalnya bermula pada pengajian di masjid, surau dan langgar dengan mengkaji al-Qur'an, Kitab-kitab Tasawuf, Aqidah, Fiqh dan Bahasa Arab (Bahaking, 2003).

Halaqah Quran merupakan sistem pembelajaran yang mengkaji Al-Quran dan ilmu-ilmu kealquranan. Dari isi pokok AL-Quran sendiri mengkaji mengenai Aqidah, ibadah, Al-Wa'du dan Al-Wa'id (Janji baik dan ancaman buruk), akhlak, 
hukum, kisah, ilmu pengetahuan dan teknologi.

Adapun metode yang digunakan dalam sistem halaqah Quran diantaranya: 1) metode tuntunan, yaitu metode yang digunakan ketika santri menyimak kitab yang dibaca atau diajarkan oleh kiai dan kiai menuntun para santri dan membetulkan tnada baca atau harakat pada kitab secara perkata atai perkalimat. 2) Metode ceramah, 3) metode hafalan, dan 4) metode suri teladan dimana metode tersebut menggunakan sosok idola untuk menjadi figur. Contohnya sahabatsahabat nabi atau yang paling dekat adalah guru Halaqah.

Oleh karena itu, dalam kegiatan halaqah Quran yang di aplikasikan kepada anak, terdapat unsur-unsur bimbingan terutama dalam konseks akhlak sebagai sistem pembelajaran untuk membentuk akhlak karimah dengan menerapkan berbagai pengetahuan dan pemahaman apa saja akhlak baik dan akhlak buruk serta menjadi acuan pengamalan untuk diamalkan dalam kehidupan sehari-hari danbekal untuk masa yang akan datang.

\section{HASIL DAN PEMBAHASAN}

SD Al-Quran merupakan salah satu sekolah yang memiliki letak strategis untuk kegiatan menghafal Al-Quran, yaitu berada dekat dengan jalan utama A.H Nasution. Kondisi alam di daerah kelas Gazebo yang masih rindang, sejuk dan teduh sehingga membuat suasana belajar yang kondusif. Lapangan dan jalanan yang bersih, rapi karena bersebelahan dengan gedung Lembaga Pengembangan Tilawatil Quran (LPTQ) sukamiskin bandung. Posisi sekolah juga dekat dengan jalan raya, sehingga memudahkan guru, orangtua, dan siswa untuk sampai di sekolah dengan menggunakan berbagai transportasi umum yang tersedia.

SD Al-Quran memprioritaskan pendidikan Al-Quran, namun tidak melepaskan Pendidikan akademik agar siswa memiliki pengetahuan dari berbagai aspek. Sistem pengajaran yang diterapkan adalah 30\% untuk kegiatan akademik dan 70\% kegiatan kealqur'anan. SD Al-Quran memiliki target pengajaran minimal 15 juz untuk siswanya. Namun diluar dugaan ada yang sudah hatam 30 juz. SD AlQuran diharapkan dapat menjadi wadah untuk anak agar menjadi generasi sesuai visi dan misi nya yaitu mencetak generasi muda yang cerdas, berakhlakqul karimah, dan Hafidz Quran.

Salah satu upaya dalam pembelajaran Al-Quran adalah melalui sistem halaqah Quran. sistem Halaqah ini mengkaji berbagai ilmu terutama bersumber dari Al-Quran. serta sebuah sistem yang didalamnya menerapkan nilai-nilai akhlakul karimah pada anak. Dari kondisi objektif tersebut, penulis melakukan penelitian mengenai bimbingan akhlak pada anak melalui sistem halaqah Quran. Data-data yang penulis sajikan diperoleh berdasarkan hasil observasi langsung aktifitas siswa di kelas dan wawancara sebagai pengukuran berhasil atau tidaknya bimbingan akhlak pada anak melalui halaqah Al-Quran. Dari hasil pengumpulan data yang penulis lakukan untuk penyajian data, penulis uraikan sebaga berikut: 


\section{Bimbingan Akhlak pada Anak melalui Sistem Halaqah Quran}

Bimbingan Akhlak pada Anak melalui Sistem Halaqah Quran

Bimbingan akhlak di SD Al-Quran dilaksanakan melalui sistem halaqah Quran. sistem Halaqah Quran ini mengajarkan barbagai kajian mengenai AlQuran dengan beberapa metode. Sesuai dengan visi SD Al-Quran yang memiliki tujuan mencetak generasi cerdas, berakhlakul karimah dan hafidz Quran. Maka dalam upaya mencapai tujuan tersebut, SD Al-Quran menerapkan sistem halaqah sebagai metode pengajaran kepada siswanya. Lebih jelasnya maka dipaparka unsur bimbingan sebagai berikut:

Pertama, Pembimbing. Pembimbing dalam aktivitas bimbingan Akhlak melalui sistem Halaqah Quran adalah guru Al-Quran. dalam satu kelas terdapat 23 pembimbing. Pembimbing yang menjadi objek penelitian penulis di SD AlQuran adalah Pembimbing kelas 2. Pendidikan Terakhir Pembimbing kelas 2 adalah SMA hal ini dikarenakan setelah mereka lulus SMA langsung mengambil pendidikan nonformal yaitu mengahfal Al-Quran. ketiga guru tersebut telah menamatkan hafalan $30 \mathrm{Juz}$ dan menjadi hafidzah. Setelah hatam, mereka mengabdi di SD Al-Quran dengan masa pengabdian kurang lebih tiga tahun.

Kedua, Terbimbing. Terbimbing adalah siswa kelas 2 dengan usia 7-8 tahun. Sebagian besar terbimbing adalah warga kota bandung atau domisili bandung. Asal terbimbing ada yang dari garut dan bandung, dan jakarta. Dari hasil observasi lapangan penulis mengamati terdapat kondisi akhlak siswa yang menonjol dalam proses halaqah Quran diantaranya: 1) Akhlak kepada guru, kekurangannya siswa tidak terlalu menurut kepada guru Al-Quran yang bukan pembimbingnya. Sehingga pembimbing tersebut harus memberikan arahan kepada siswa yang dituju secara berulang. Namun kelebihannya siswa mudah mematuhi komitmen yang dibuat oleh pembimbing. 2) Akhlak terhadap diri sendiri, dari aspek jasmani siswa cukup menjaga kerapihan dan kebersihan diri. 3) Akhlak terhadap teman, kelebihan yang dilihat dari akhlak kepada teman adalah sifat saling membantu. Akhlak tersebut terekam ketika penulis mengamati seorang siswa perempuan yang mencoret-coret lantai dengan spidol permanen, pembimbing membimbing siswa tersebut untuk bagaimana agar siswa tersebut dapat menyelesaikan masalah yang bersumber dari dirinya. Yaitu dengan cara mempercayakan siswa tersebut untuk bertanggung jawab menghapus coretan yang ada di lantai. Dalam upaya menyelesaikan masalah yang dihadapi, terdapat salah satu teman yang membantu menghapus coretan sehingga coretan tersebut perlahan memudar. Sementara kekurangan akhlak yang terlihat adalah masih ada anak yang berkelahi sampai salah satu anak tersebut menangis.

Ketiga, materi bimbingan akhlak pada anak melalui sistem halaqah Quran. 1) Materi InspirasiQu, Materi yang digunakan dalam kegiatan inspirasiQu diadopsi dari kisah isnpiratif sahabat nabi. Salah satu contoh materi inspirasiQu adalah kisah sahabat yaitu Nu'aim bin Mas'ud R.a seorang sahabat nabi yang telah 
mendapatkan hidayah kemudian mengabdi kepada islam dan mengorbankan tenaga, harta dan jiwanya di jalan Allah. 2) Materi Ziyadah dan Murojaah, Materi Ziyadah dan Murojaah berbeda-beda tergantung kemampuan siswanya, namun dikelas 2 terdapat tergetan penyampaian materi yaitu QS As-Syam sampai QS AnNas, kemudian tahap kedua yaitu QS Al-Balad sampai QS An-Naba. 3) Materi Hadits, Dalam halaqah Quran, fungsi hadits terhadap Al-Quran sebagai penjelas apa yang dikehendaki oleh Al-Quran. materi yang disampaikan kepada siswa adalah materi hadits-hadits pendek yang berkaitan erat dengan pembentukan akhlak.

Keempat, Metode bimbingan akhlak pada anak melalui sistem halaqah Quran. Sistem Halaqah Quran memiliki berbagai metode diantaranya metode tuntunan, yaitu metode dimana guru Al-Quran menuntun siswanya untuk membenarkan bacaan dan hafalannya. Metode ceramah, yaitu guru Al-Quran menjelaskan berbagai materi contohnya materi hadist bagaimana makna yang terkandung dalam hadits pendek yang bisa diaplikasikan dikehidupan sehari-hari. Metode hafalan, yaitu metode unggulan SD Al-Quran dimana siswa dituntut untuk menghafal Al-Quran serta menghafal hadist-hadist pendek. Terakhir adalah metode suri teladan, metode ini mengadopsi kisah-kisah sahabat nabi sebagai inspirasi siswa dan dapat dijadikan sebagai teladan.

Kelima, media bimbingan akhlak pada anak melalui sistem halaqah Quran. Media yang digunakan dalam pengajaran sistem tersebut yaitu: 1) Al-Quran, AlQuran sebagai media dan sumber unama dalam Halaqah Quran. Al-Quran dibaca, dihafal dan dipelajari sesuai kapasitas siswa agar mudah difahami. Sejauh ini belum ada anjuran menggunakan Al-Quran jenis tertentu untuk menghafal Al-Quran. 2) Buku Tahsin, dengan menggunakan Tahsin Taqiya yaitu suatu metode tahsin yang dirancang khusus oleh para asatiz dari Pondok Quran Boarding School. 3) Banner, media Banner digunakan untuk pembelajaran Tahsin, dibuat semenarik mungkin agar siswa semangat belajar. 4) Buku Hadist, digunakan sebagai pegangan Pembimbing guna penyiapan materi hadits-hadist pendek.

Keenam, Tujuan bimbingan akhlak pada anak melalui sistem halaqah quran. Halaqah Quran dirancang untuk dapat memenuhi tujuan dari SD AlQuran. sesuai dengan salah satu misinya yaitu melakukan pembinaan intensif untuk mencetak generasi yang hafidz Quran maka halaqah Quran menjadi alat untuk mencapai tujuan tersebut. kegiatan halaqah Quran di SD Al-Quran hanya terdiri dari satu Pembimbing selaku pembimbing dan beberapa siswa dengan membentuk kelompok kecil. Tujuanya agar Pembimbing lebih leluasa untuk membimbing dan merangkul siswanya lebih dekat. Mengetahui karakteristik siswa lebih detail. Sehingga jika Pembimbing banyak mengenal siswanya, maka kegiatan belajarpun akan terlaksana dengan intensif. (wawancara dengan ibu Evie Latifah tanggal 6 Agustus 2018). Setelah mengenal siswa lebih baik, Pembimbing lebih 
leluasa membimbing siswanya mengenai adab-adab ketika belajar, sehingga berpengaruh kepada akhlak siswa dan proses mengajarpun terlaksana dengan intensif (wawancara dengan ibu Hasna pada tanggal 6 Agustus 2018)

Halaqah Quran juga bertujuan untuk mengajarkan kepada siswa bagaimana menghadapi dinamika kelompok, bagaimana membangun kedekatan dengan siswa kelompoknya dan mengenal lebih dekat Pembimbing dan teman sebayanya. Agar lebih jelas, penulis gambarkan dalam bentuk tabel.

\section{Tabel 1}

Bimbingan Akhlak pada Anak Melalui Sistem Halaqah Quran

\begin{tabular}{|c|c|c|c|c|}
\hline $\begin{array}{c}\text { Sistem Halaqah } \\
\text { Quran }\end{array}$ & Materi & Metode & Media & Tujuan \\
\hline InspirasiQu & $\begin{array}{l}\text { Kisah-kisah sahabat } \\
\text { nabi }\end{array}$ & Cerita & $\begin{array}{l}\text { Sound, } \\
\text { Micorofon, } \\
\text { terpal } \\
\text { untuk alas }\end{array}$ & $\begin{array}{l}\text { Agar anak menela- } \\
\text { dani kisah sahabat } \\
\text { rasul dan akhaknya }\end{array}$ \\
\hline $\begin{array}{l}\text { Ziyadah } \\
\text { (Menambah } \\
\text { Hafalan) }\end{array}$ & $\begin{array}{l}\text { Tahap 1: QS. Asy- } \\
\text { Syam sampai QS. } \\
\text { An-Anas } \\
\text { Tahap } 2 \text { QS An- } \\
\text { Naba sampai Al- } \\
\text { Balad } \\
\text { Tahap 3: Juz } 29\end{array}$ & $\begin{array}{l}\text { Hafalan } \\
\text { dengan } \\
\text { metode } \\
\text { Talaqqi }\end{array}$ & $\begin{array}{l}\text { Al-quran } \\
\text { dan buku } \\
\text { mutabaah }\end{array}$ & $\begin{array}{l}\text { Target kelas } 2 \text { selesai } \\
\text { juz } 30\end{array}$ \\
\hline $\begin{array}{l}\text { Murojaah } \\
\text { (mengulang dan } \\
\text { menguatkan } \\
\text { Hafalan yang } \\
\text { ada) }\end{array}$ & $\begin{array}{l}\text { QS Al-Buruj untuk } \\
\text { kegiatan bersama, } \\
\text { namun untuk } \\
\text { hafalan murojaah } \\
\text { surat masing-masing }\end{array}$ & $\begin{array}{l}\text { Hafalan } \\
\text { dengan } \\
\text { metode } \\
\text { Talaqqi }\end{array}$ & $\begin{array}{l}\text { Al-Quran } \\
\text { dan buku } \\
\text { mutabaah }\end{array}$ & $\begin{array}{l}\text { Untuk penguatan } \\
\text { hafalan }\end{array}$ \\
\hline Hadits & $\begin{array}{l}\text { Hadits-hadits } \\
\text { pendek }\end{array}$ & $\begin{array}{l}\text { Hafalan } \\
\text { dengan } \\
\text { metode } \\
\text { talaqqi }\end{array}$ & $\begin{array}{l}\text { Papan } \\
\text { tulis, } \\
\text { spidol } \\
\text { dan } \\
\text { Buku } \\
\text { hadits }\end{array}$ & $\begin{array}{l}\text { Untuk menghafal dan } \\
\text { menerapkan unsur- } \\
\text { unsur akhlak yang } \\
\text { terkandung dalam } \\
\text { hadits }\end{array}$ \\
\hline
\end{tabular}

Sumber: Hasil wawancara bersama ibu Qonitat pada tanggal 6 Agustus 2018

Dari Tabel 1, telah kita ketahu bagaimana gambaran bimbingan Akhlak pada Anak melalui sistem halaqah Quran. serangkaian kegiatan Halaqah Quran menjadi perantara untuk penanaman Akhlak pada Anak. Dari kegiatan pembelajaran Al-Quran, guru Al-Quran selaku pembimbing membimbing dengan baik siswanya agar dapat sama-sama mecapai tujuan bimbingan. Contohnya target 
hafalan al-Quran yang tentunya secara individu memiliki keberagaman kemampuan. Untuk mencapai target tersebut, akhlak siswa selaku terbimbing sangat diperhatikan. Bagaimana siswa berkahlak terhadap gurunya yang mengajarkan Al-Quran, terhadap diri sendiri untuk mencaoai targetan, dan bagaimana berkahlak kepada teman yang pada dasarnya sama-sama berjuang untuk mencapai sebuah keberhasilan.

Perhatian terhadap akhlak dirasakan sangat penting, terutama kepada anak. Oleh karena itu perlu adanya bimbingan untuk mengarahkan anak dalam membentuk akhlak yang baik "anak-anak mengalami keguncangan, bila tidak tepat penyalurannya dan tidak mendapat bimbingan yang baik akan menimbulkan akibat negatif seperti nakal yang ditibulkan dan direalisasikan oleh perbuatan jasmaninya misalnya suka melempar, memanjat, mengganggu orang lain dan sebagainya. Dalam hal ini maka orang tualah yang memiliki tanggungjawab dalam mendidik, membimbing, dan mengarahkan anaknya dengan contoh yang baik (Hasyim, 1983: 95)

Para orang tua, ulama, termasuk para pembimbing mempunyai tanggung jawab dalam membina dan membimbing akhlak mulia yakni meluruskan segala penyimpangan perilaku manusia, menepis segala perilaku tercela untuk kemudian memenuhi segenap jiwa dengan perilaku yang berniali akhlakul karimah. Bimbingan Akhlak melalui pembelajaran Al-Quran selaras dengan penuturan Muhammad Muhyidin dalam bukunya berjudul" Mengajar Anak Berakhlak AlQuran”, mengapa Al-Quran perlu difahami sejak anak-anak? Pengarang berpendapat jika anak memahami AL-Quran sejak dini maka Akhlaknya akan bagus. Salah satu bukti nyata untuk memelihara kemurnian al-Quran adalah dengan menghafalkannya, karena menghafalkan al-quran merupakan suatu pekerjaan yang sangat mulia dihadapan manusia apalagi dihadapan Allah Swt (Muhyidin, 2004:5).

\section{Faktor penghambat dan Penunjang Bimbingan Akhlak pada Anak}

Selama proses pelaksanaan Bimbingan Akhlak melalui Sistem Halaqah Quran terdapat beberapa faktor penunjang dan penghambat. Dari hasil wawancara bersama ibu Evie Latifah pada tanggal 6 Agustus 2018 faktor-faktor tersebut diuraikan sebagai berikut:

Faktor penunjang yang ditemukan dalam penelitian adalah: pertama, Pembimbing memiliki peran yang cukup kuat dan menjadi figur bagi siswa binaannya dalam Halaqah Quran. Kedua, Komunikasi antara Pembimbing dengan siswa yang kuat. Upaya-upaya Pembimbing untuk membimbing siswanya dengan cara komunikasi intim atau bimbingan pribadi. Sehingga setiap siswa mendapat bimbingan atau nasihat yang berbeda sesuai dengan kebutuhan siswa. Contohnya siswa dibimbing secara individu mengenai akhlak tentang makan, maka pembimbing membimbing siswanya agar senantiasa memperhatikan adab 
makan, yaitu jangan makan sambil berdiri.

Ketiga, Pembimbing gigih memberikan komitmen yang dibuat dengan siswa. Komitmen tersebut berupa adab-adab ketika belajar. Salah satu contohnya, ketika ada siswa yang berbuat salah dna membuat temannya menangis, maka konsekuensinya siswa yang bersalah dan siswa yang menangis belajar di luar untuk seentara, tujuannya agar kedua siswa tersebut dapat kemabli membangun kedekatan dan memecahkan masalah bersama. Dalam hal tersebut siswa Jika siswa diingatkan mengenai komitmen, maka siswa kembali patuh terhadap arahan guru tersebut. Keempat, Penyambutan, ketika siswa datang ke sekolah, Pembimbing melakukan penyambutan dengan ramah. Hal ini bertujuan agar Pembimbing dapat membangun kedekatan dengan siswa dan siswa tersebut tidak bergantung kepada orang tuanya yang telah mengantarkannya sampai gerbang sekolah. Karena banyak ditemukan siswa yang masih belum mandiri ketika berpisah dengan orang tuanya ketika berangkat sekolah. hal ini menjadi penghambat proses belajar siswa tersebut karena masih bergantung kepada orang tua dan selalu mengharapkan kehadiran orang tua.

Aktivitas Bimbingan Akhlak melalui Halaqah Quran juga tidak terlepas dari berbagai kendala yang menjadi faktor penghambat. Faktor penghambat yang ditemukan diantaranya: pertama, Pengkondisian siswa yang cenderung berjalan lambat karena siswa yang susah diatur. Pengkondisian siswa ketika kegiatan Halaqah Quran hendak dimulai, dikelas 2 terdapat 3 guru Al-Quran dengan memegang masing masing siswa binaannya. Jika salah satu guru Al-Quran tidak ada atau belum hadir, maka kelompok siswa yang dibina guru tesebut terbilang sulit bergabung dengan dua kelompok lain. Kedua, Pembimbing memiliki siswa binaannya masing-masing, sehingga ketika hendak membimbing siswa binaan guru lain, Pembimbing tersebut kesulitan memahami karekteristik siswa tersebut. Dan akhirnya siswa yang dituju lambat untuk mematuhi apa yang Pembimbing Arahkan.

Ketiga, Karakteristik siswa yang beragam, mengenai sikap, kemandirian anak masih terlihat manja dan acuh. Keempat, Adanya sistem Rolling Pembimbing, sehingga ketika siswa binaan sudah nyaman dengan Pembimbingnya harus beradaptasi kembali. Walaupun kegiatan Rolling guru tersebut dilakukan setahun sekali namun berpengaruh terhadap siswa. Bahkan kadang orang tua siswa berharap agar setiap tahunnya siswa dibina atau dibimbing oleh guru Al-Qran yang sama. Akan tetapi, pendapat lain dari pihak guru al-Quran untuk merolling setiap guru Al-Quran, tujuannya agar siswa tidak bergantung kepada satu guru Al-quran saja. Siswa dituntut untuk beradaptasi dengan guru AlQuran binaannya yang baru.

Faktor penunjang dan penghambat memang tidak pernah terlepas dari kehidupan umat manusia. Oleh karena itu, faktor penghambat dan faktor penunjang yang berpusat kepada anak tidak dapat disalahkan kepada anak. Karena 
dilihat dari masa kanak-kanak yang masih menyerap banyak hal dan sifat dasar anak yang memiliki kerakteristik yang unik.

Masa usia anak sekolah adalah transisi dalam interaksi sosial yaitu terjadinya perubahan figur tokoh yang akan berpengaruh pada diri anak. Dalam hal ini tokoh ibu akan digantikan oleh guru. Menurut subarsono keberhasilan proses belajar mengajar sangat ditentukan oleh kemampuan guru dalam mengelola proses belajar mengajar (Supartini, 2004).

Oleh karena itu kembali kepada peran guru yang memiliki peranan sangat penting dimata siswa. Sebagai figur yang dapat di contoh dalam penanaman Akhlak. Figur utama salah satu contohnya ketika guru menceritakan kisah para sahabat nabi untuk di teladani, guru lah selaku pembimbing yang akan menjadi contoh pertama yang meeladani kisah sahabat nabi yang kemudian akan menginspirasi siswanya kemudian untuk diamalkan oleh siswa dalam kehidupan sehari-hari.

Guru merupakan figur pengganti orang tua bagi anak-anak disekolah, yang memberikan andil yang besar dalam tumbuh kembang mereka. Guru akan memberikan perlindungan, pengajaran, dan kebiasaan-kebiasaan baru yang mendukung. Sikap yang harus dimiliki oleh seorang guru yaitu: tegas berwibawa, memberi contoh dengan tindakan, percaya diri, konsistwn, dan memahami kejiwaan peserta didik

\section{Output bimbingan Akhlak pada Anak melalui Halaqah Quran}

Pembentukan Akhlak menurut Abudin Nata dapat diartikan sebagai usaha sungguh-sungguh dalam rangka membantuk anak, dengan menggunakansarana pendidikan, pembinaan yang terprogram dengan baik dan dilaksanakan dengan sungguh-sungguh dan konsisten. Pembentukan akhlak ini dilakukan berdasarkan asumsi bahwa akhlak adalah hasil usaha pembinaan bukan terjadi dengan sendirinya (Nata, 2010: 4).

Pembinaan yang terprogram di SD Al-Quran adalah memlalui kegiatan Halaqah Quran. dimana kegiatan Halaqah Quran tersebut dilaksanakan setiap hari di waktu sekolah secara kontinyu. Berdasarkan hasil observasi dan wawacara dengan pembimbing pada tanggal 6-7 Agustus 2018, bahwa bimbingan Akhlak melalui sistem Halaqah Quran berjalan lancar dan dapat dikatakan cukup berhasil.

Terbukti dengan adanya perubahan secara signifikan mengenai akhlak siswa yang dilaporkan oleh Orang tua siswa kepada Guru Al-Quran yang membimbing anaknya. (wawancara dengan ibu Qonitat tanggal 7 Agustus 2018).

Perubahan yang dirasakan oleh pembimbing terhadap siswanya dapat dikategotikan sebagai berikut: Pertama, Akhlak Terhadap Allah Swt. Berdasarkan laporan orang tua, perubahan yang dirsakan adalah anak yang mau melaksanakan shalat dirumah, padahal sebelumnya anak tersebut tidak pernah melaksanakan shalat di rumah. Siswa tersebut terbiasa melakukan shalat berjamaah di sekolah, 
namun siswa tersebut belum menerapkannya di rumah. Namun karena bimbingan yang diberikan oleh guru Al-Quran selaku pembimbing yang dilakukan secara individu, siswa tersebut menadi mau untuk melakukan shalat jamaah di rumah.

Kedua, Akhlak Terhadap Orang tua, Siswa mau membantu orang tuanya melakukan beberapa pekerjaan ringan di rumah seperti mencuci piring, membantu memasak dan sebagainya. Dari sisi sopan santun, siswa sudah mulai baik dalam berakhlak, contonhnya memberi salam kepada orang tua ketika siswa berpmit untuk belajar disekolah, kemudian siswa sudah mau belajar mandiri untuk tidak merepotkan orangtuannya agar senantiasa menunggu siswa tersebut selama sekolah.

Ketiga, Akhlak terhadap guru, Siswa sudah mampu mematuhi adab-adab sebelum belajar, walaupun harus diingatkan secara kontinyu. Siswa menerima konsekuensinya, belajar bertanggung jawab ketika dirinya melakukan kesalahan, bersikap tertib, rapih, menolong guru membawakan buku, penghapus papan tulis, atau beberapa media yang dibutuhkan selama kegiatan belajar. antri dalam kegiatan setoran hafalan dan memperhatikan guru dengan seksama. Keempat, Akhlak terhadap diri sendiri, Siswa secara bertahap sudah mampu untuk mandiri, padahal sebelumnya siswa tersebut manja dan sering menangis. Siswa sudah mampu untuk memeprhatikan adab-adab ketika sedang makan.

Kelima, Akhlak terhadap teman, Seperti yang telah dijelaskan mengenai kondisi terbimbing, siswa saling mambantu menyelesaikan masalah yang dihadapi temannya. Memiliki akhlak baik yang lainnya seperti saling berbagi makanan, dan mengingatkan teman ketika melakukan salah. Contohnya makan sambil berdiri siswa berani untuk mengngatkan bahwa makan sambil berdiri adalah hal yang tidak baik, siswa mengingatkan dengan penyampaian yang baik misalnya dengan mengingatkan hadist adab makan yang telah dihafal bersama. Dan terakhir, Kegatan meghafal bersama menjadi momentum kebersamaan untuk sama-sama meraih kebaikan untuk Akhirat kelak.

Adapun keberhasilan lainnya dapat dari hasil wawancara bersama 6 Siswa dari 18 siswa yang ada. Secara pemahaman, siswa sudah mampu memahami bagaimana akhlak yang baik yang harus dilakukan. Mampu mengklasifikasikan secara sederhana ruang lingkup akhlak diantaranya akhlak terhadap Allah swt, Akhlak terhadap Orang tua, Akhlak terhadap guru, Akhlak terhadap diri sendiri dan Akhlak terhadap teman.

Dari aspek penerapan atau pengamalan akhlak, siswa kelas dua masih belum terlalu memahami bagaimana akhlak yang baik dan akhlak yang buruk yang perlu untuk mereka amalkan. Contohnya siswa mengetahui bahwa setiap belajar haruslah memperhatikan adab-adab belajar, bersikap rapih, tertib dan menyimak apa yang guru terangkan dengan seksama, namun dalam kenyataannya siswa masih harus banyak diingatkan. Pembimbing masih harus sabar untuk mengingatkan secara terus menerus. 
Sesuai dengan pemaparan Abudin Nata, Agar pembinaan Akhlak memperolah hasil yang memuaskan, diperlukan cara atu metode. metode yang dapat ditempuh dalam pembinaan akhlak ini adalah pembiasaan yang dilakukan sejak kecil dan terus secara kontinyu. Dalam pembinaan atau bimbingan akhlak, pembiasaan mempunyai peranan penting dalam kehidupan manusia, hal ini dikarenakan ia dapat menghemat banyak sekali kekuatan manusia. Islam menggunakan kebiasaan itu sebagai salah satu teknik pendidikan, yang mengubah sifat-fifat manusia menjadi kebiasaan. Jika manusia membaiasakan berbuat jahat, maka ia akan menjadi orang jahat, jika manusia menghendaki ia menjadi pemurah maka ia harus membiasakan dirinya untuk melakukan pekerjaan yang bersifat pemurah., hingga murah hati dan murah tangan itu menjadi tabiatnya yang mendarah daging (Nata, 2010: 32).

Dalam membentuk Akhlak karimah, selain dengan program Pendidikan melalui halaqah Quran yang bersifat kontinyu, Halaqah Quran di SD Al-Quran juga membiasakan melakukan kegiatan kealquranan. Diantaranya, siswa dibiasakan untuk bertilawah, dibiasakan untuk menghafal Al-Quran berupa Ziyadah dan Murojaah dan dibiasakan untuk menghafal hadits-hadist pendek agar hafalan demi hafalan menyerap dalam jiwa dan secara tidak langsung menjadi tameng diri bagi siswa untuk melakukan akhlak yang tidak baik. Selain itu, siswa dibimbing untuk membiasakan memperhatikan adab-adab belajar dan konsekuensi yang didapat apabila siswa tidak mengikuti aturan yang telah disepakati bersama. Tentunya dari pembiasaan-pembiasaan tersebut akan mempengaruhi terhadap pembentukan akhlak.

Sistem Halaqah Quran menjadi sarana bimbingan Akhlak yang cukup Efektif. Karena kegiatan Halaqah Quran dilakukan secara kekeluargaan, pembimbing sudah seperti orang tua terbimbing. Lingkungan halaqah Quran menjadi lebih intensif karena terdiri dari kelompok-kelompok kecil. Sehingga kegiatan bimbinganpun dapat tersampaikan dengan baik.

Beberapa keberhasilan yang dicapai dalam kegiatan bimbingan akhak melalui sistem halaqah Quran bukan merupakan sebuah Akhir, namun harus menjadi pendorong untuk lebih baik lagi, karena pada dasarnya anak usia 7-8 tahun masih memerlukan banyak bimbingan demi bekal kehidupannya dan untuk membentuk akhlak karimah secara optimal yang dapat mendarah daging dalam dirinya.

\section{PENUTUP}

Berdasarkan hasil penelitian dapat disimpulkan bahwa bimbingan akhlak pada anak melalui sistem Halaqah Quran memiliki 4 kegiatan pembelajaran yaitu InspirasiQu (kisah-kisah sahabat nabi), ziyadah (menambah hafalan), Murojaah (mengulang dan menguatkan hafalan yang sudah ada), dan pengajaran hadits 
pendek. Keempat kegiatan tersebut memiliki unsur bimbingan dalam membentuk akhlak siswa.

Halaqah Quran dirancang untuk dapat memenuhi tujuan dari SD AlQuran. sesuai dengan salah satu misinya yaitu melakukan pembinaan intensif untuk mencetak generasi yang hafidz Quran maka halaqah Quran menjadi alat untuk mencapai tujuan tersebut. kegiatan halaqah Quran di SD Al-Quran hanya terdiri dari satu Pembimbing selaku pembimbing dan beberapa siswa dengan membentuk kelompok kecil. Tujuanya agar Pembimbing lebih leluasa untuk membimbing dan merangkul siswanya lebih dekat. Mengetahui karakteristik siswa lebih detail. Sehingga jika Pembimbing banyak mengenal siswanya, maka kegiatan belajarpun akan terlaksana dengan intensif.

Faktor penghambat dan faktor penunjang Bimbingan Akhlak pada Anak melalui Sistem Halaqah Quran memiliki keterkaitan, contohnya peranan Pembimbing sebagai figur menjadi penunjang terlaksananya kegiatan bimbingan melalui sistem halaqah Quran. Pembimbing membangun kedekatan dengan siswa sehingga siswa dengan mudah dibimbing dan diberi nasihat bagaimana beradab dan berakhlak. Faktor penunjang yang diciptakan pembimbing berupa komunikasi atau bimbingan pribadi, membangun komitmen dengan berbagai aturan yang disepakati, dan penyambutan pembimbing kepada siswa.

Namun peran pembimbing juga menjadi penghambat ketika pembimbing tidak ada, maka anak binaanpun cenderung susah untuk dikondisikan. Karena siswa enggan mematuhi arahan dari pembimbing lain. Maka proses pelaksanaan Halaqahpun cenderung alot dan bimbingan yang diberikan oleh pembimbing direspo dengan lambat oleh siswa.

Hasil yang dicapai dari bimbingan akhlak pada anak melalui sistem halaqah Quran diketahui berlangsung dengan efektif dan cukup berhasil. Dampaknya dapat dirasakan oleh Guru Al-Quran selaku pembimbing dan orang tua siswa yang melaporkan perubahan akhlak siswa yang diaplikasikan di rumah. Secara pemahaman, siswa sudah mampu memahami bagaimana akhlak yang baik yang harus dilakukan. Mampu mengklasifikasikan secara sederhana ruang lingkup akhlak diantaranya akhlak terhadap Allah swt, Akhlak terhadap Orang tua, Akhlak terhadap guru, Akhlak terhadap diri sendiri dan Akhlak terhadap teman.

\section{DAFTAR PUSTAKA}

Amin, S. (2002). Pengantar Studi Islam, Semarang: Pustaka rizki putra

Arifin, I.Z. ( 2008). Bimbingan dan Konseling Islam Berbasis Ilmu Dakwah (AlIrsyad Wa Al-Tawjih Al-Islam), dalam Ilmu dakwah: Academic Journal Homiletic Studies, 4 (11), 27-1092

Armansyah. (2018). Penerapan Sistem Pembinaan Halaqah untuk Meningkatkan Kecerdasan Emosional, TAJDID: Jurnal Pemikiran Keislaman dan Kemanusiaan, 2(1). 
S. Hajrina., D.I. Effendi., \& A. Mujib.

Bahaking, R. (2003). Jejak Perubahan Pendidikan Pesantren. Jakarta:Prodatama Wira Gemilang

Chodijah, S. (2016). Model Bimbingan dan Konseling Komprehensif dalam Meningkatkan Akhlak Mahasiswa, Ilmu Dakwah: Academic Journal for Homiletic Studies, 10(1), 129-146.

Enjang, A.S., \& Mujib, A. (2009) Dasar-Dasar Bimbingan dan Penyuluhan Islam. Bandung: Sajjad Publishing House

Gustini, N. (2016). Bimbingan dan Konseling melalui Pengembangan Akhlak Mulia Siswa Berbasis Pemikiran Al-Ghazali, Tadris: Jurnal keguruan dan Ilmu Tarbiyah, 1(1).

Hikmat. (2016). Bimbingan Akhlakul Karimah dan Perilaku Narsisme Remaja, AN-NID A: Scientific Journal for Da'wa Studies, 15(2).

Lubis, S.H. (2011). Menggairakan Perjalanan Halaqah, Yogyakarta : Pro You

Lusiyana, A., Rohman, F., \& Rohim, S. (2018). Peran Bimbingan Konseling Berbasis Tiga Pilar (Guru, Orang Tua, dan Lingkungan Masyarakat) dalam

Pembentukan Akhlakhul Karimah Siswa di MA Nurul Huda Kabupaten

OKU Timur, RISTEKDIK: Jurnal Bimbingan dan Konseling, 3(2).

Mansur, M. (2009). MunaPendidikan Anak Usia Dini dalam Islam, Yogyakarta: Pustaka Pelajar

Matta, A. (2006). Membentuk Karakter Cara Islam, Jakarta: AlI 'tishom

Muhyidin, M. (2004). Mengajar Anak Berakblak al-Qur'an, Bandung:Remaja Rosdakarya

Munawaroh, A. (2009). Pendidikan Ibadah. Yogyakarta : PT. Dina Utama

Munawwir, A.W. (1997). Al-Munawwir: Kamus Arab - Indonesia

Nashir, A., \& Halib, A. (2016). Sistem Pembinaan Halaqah terhadap Kecerdasan

Emosional Santri di Markaz Tahfidz Al-quran Al-Birr, TARBAWI: Jurnal Pendidikan Agama Islam, 1(2).

Nata, A.(2010). Akhlak Tasawuf. Jakarta: PT Raja Grafindo.

Satriah, L. (2016). Panduan Bimbingan Konseling Pendidikan, Bandung: CV Mimbar Pustaka

Subarsono. (1989). Etika Islam Tentang Kenakalan Remaja, Jakarta: Bina Aksara

Suhid, A.(2009). Pendidikan Akblak dan Adab Islam. Kuala Lumpur: Maziza SDN.BHD.

Supartini, Y. (2004). Buku Ajar Dasar Keperawatan Anak., Jakarta: EGC. 